Témoigner Témoigner. Entre histoire et mémoire

Getuigen Revue pluridisciplinaire de la Fondation Auschwitz

$121 \mid 2015$

Violences radicales en scène

\title{
The Look of Silence: spreken of zwijgen?
}

\section{Gorik de Henau}

\section{(2) OpenEdition}

\section{Journals}

Édition électronique

URL : https://journals.openedition.org/temoigner/3147

DOI : 10.4000/temoigner.3147

ISSN : 2506-6390

Éditeur :

Éditions du Centre d'études et de documentation Mémoire d'Auschwitz, Éditions Kimé

Édition imprimée

Date de publication : 1 octobre 2015

Pagination : 5-7

ISSN : 2031-4183

\section{Référence électronique}

Gorik de Henau, «The Look of Silence: spreken of zwijgen?», Témoigner. Entre histoire et mémoire [Online], 121 | 2015, Online op 01 octobre 2016, geraadpleegd op 04 février 2022. URL: http:// journals.openedition.org/temoigner/3147 ; DOI: https://doi.org/10.4000/temoigner.3147 


\section{THE LOOK OF SILENCE: SPREKEN OF ZWIJGEN?}

_ Adi neemt een oogtest af bij de voormalige leider van een doodseskader, die betrokken was bij de moord op zijn broer.

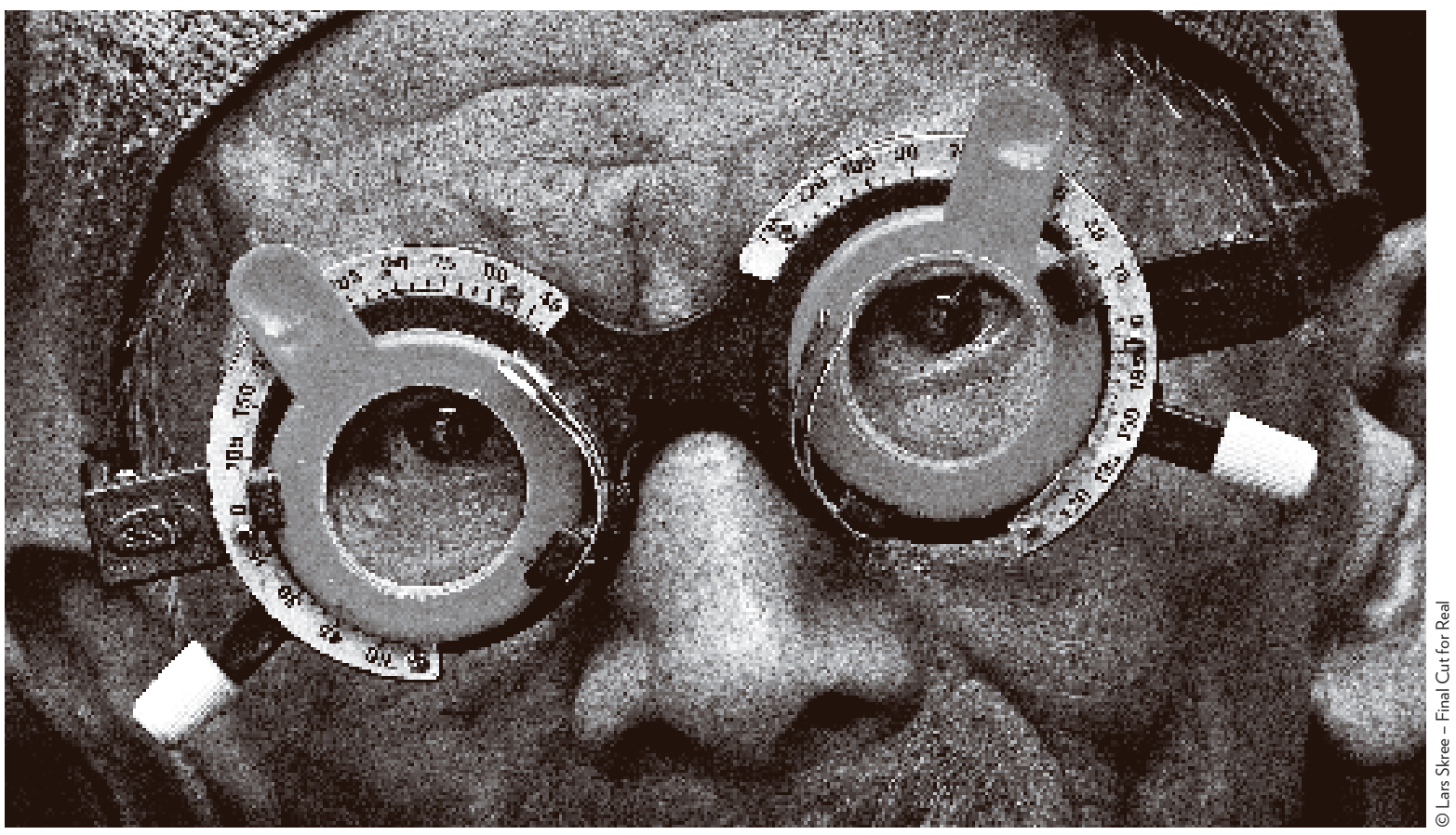

FILM Met The Look of Silence draaide de Deens-Amerikaanse documentarist Joshua Oppenheimer een vervolg op The Act of Killing (2012).

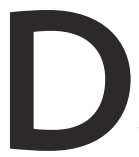

aarmee had hij een BAFTA (de hoogste Britse filmonderscheiding) gewonnen, een Oscarnominatie voor de beste documentaire uit de brand gesleept en nog een ellenlange reeks prijzen behaald (onder meer op documentairefestivals in Praag, Sheffield, Yamagata en op CPH:DOX). In de titel The Look of Silence kun je een ironische verwijzing zien naar The Look of Love, de romantische sixties-song van Burt Bacharach en Hal David, vooral bekend in de versie van Dusty Springfield. Maar het onderwerp is ditmaal verre van romantisch, want de film gaat opnieuw over de massale moord op vermeende communisten na de mislukte militaire staatsgreep in Indonesië in 1965-1966. Afhankelijk van de bron werden daarbij een half tot één miljoen mensen om het leven gebracht.

Het verschil tussen beide films is markant. Waar The Act of Killing vertrok vanuit de daders en een caleidoscopisch beeld schetste, kaart The Look of Silence één concreet geval aan vanuit het standpunt van de slachtoffers. Adi, 44 jaar oud en opticien van beroep, onderzoekt het zicht van een reeks mensen en stelt hen en passant wat vragen. Het blijkt te gaan om personen die betrokken waren bij de moord op zijn oudere broer. Hij wordt niet gemotiveerd door wraak, maar wil •.• 
•. nagaan of de bewuste figuren of hun nazaten berouw tonen. Daartussenin zitten scènes over de ravage die de gebeurtenissen in zijn eigen familie hebben aangericht. Zijn stokoude moeder verzorgt zijn seniele vader, die zo goed als doof en blind is. Geen van beiden is het gebeurde ooit te boven gekomen, temeer omdat de moordenaars nog altijd ongestraft rondlopen en in de gemeenschap zelfs voor helden doorgaan.

De structuur van de film wordt opgehangen aan Adi's interviews. De reacties op zijn vragen zijn uiteenlopend. De directe betrokkenen antwoorden met frasen die er zo vlotjes uitkomen dat je vermoedt dat ze die al talloze keren in vergelijkbare situaties hebben gebruikt. Sommigen roepen het staatsbelang in dat ze 'belangeloos' dienden. Anderen beroepen zich op de oorlogsomstandigheden; ze voerden alleen bevelen van hogerhand uit en in een oorlog vallen nu eenmaal slachtoffers. Hoger geplaatsten, voor wie dit argument niet opgaat, beweren dat ze werden gesteund door het volk, dat de communisten zou hebben 'gehaat'. Los van de semantische inhoud van wat ze zeggen, springt bij de leidinggevenden vooral de manier waarop ze hun verhaal brengen in het oog. Met een guitige blik en een ironische houding, compleet met monkellachje, pareren ze Adi's vragen. Een en ander roept herinneringen op aan sommige Poolse getuigen in Shoah van Claude Lanzmann, die hun leedvermaak over het lot van de gedeporteerden nauwelijks konden verbergen.

Familieleden van de betrokkenen reageren op een andere manier. Ze beweren er niets van geweten te hebben, want hun vader vertelde er nooit over. Ze roepen op om geen oude wonden te openen, want zijn ze niet allemaal vrienden? Eén enkele vrouw vraagt in naam van haar vader, die aan haar zijde zit en wiens geest het laat afweten, om vergiffenis. Bij dit alles komt Joshua Oppenheimer maar eenmaal tussen, in een scène helemaal aan het einde van de film. Wanneer hij de familieleden (echtgenote en volwassen zonen en dochters) confronteert met de wandaden van hun intussen overleden echtgenoot en vader, reageren die eerst ontwijkend en vervolgens agressief. Oppenheimer laat niet af en toont op zijn laptop beeldfragmenten waarin de beul zijn daden tot in de (bloederige) details beschrijft. Maar 's mans misdaad is zo overweldigend dat zijn nazaten er liever niets mee te maken hebben.

Eén keer word je je als kijker impliciet bewust van Oppenheimers aanwezigheid achter de camera. Adi legt een dader, de leider van het plaatselijke doodseskader, het vuur aan de schenen, waarop de man weer-

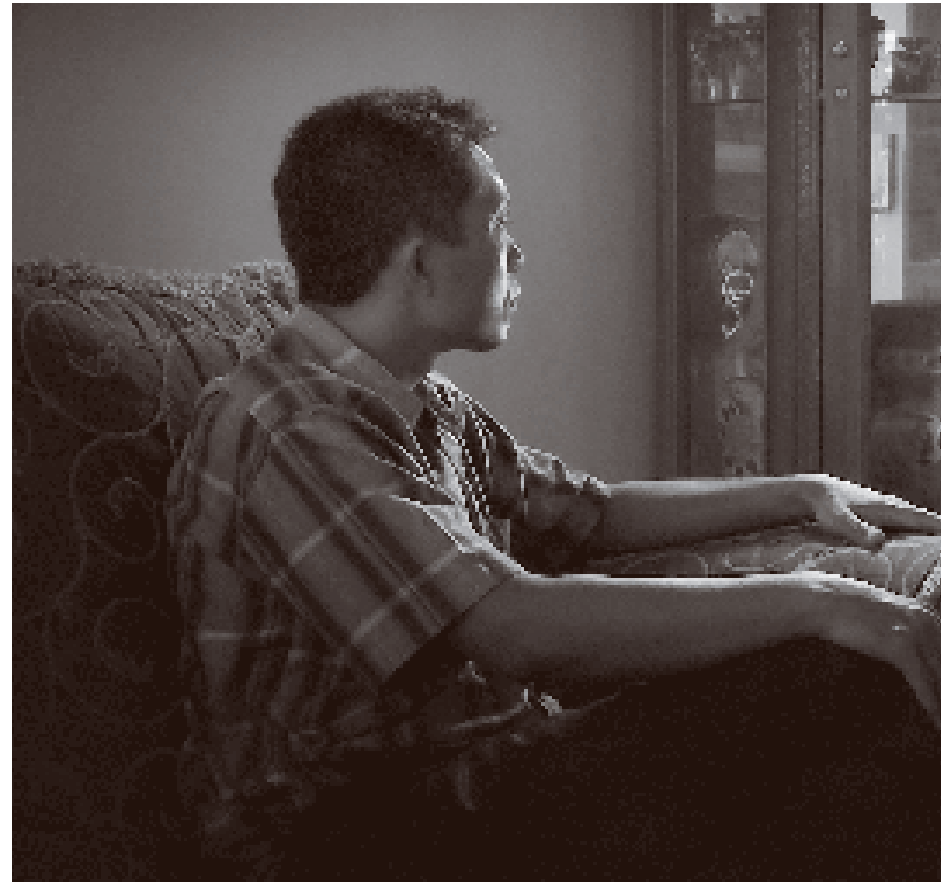

barstig wordt. 'Je vragen zijn te politiek', klinkt het, maar als Adi aandringt, kijkt de man rechtstreeks in de camera en vraagt Joshua, die hij met zijn voornaam aanspreekt, om te stoppen met filmen. Treffend is ook hoe bepaalde geïnterviewden Adi trachten bang te maken als die naar hun gevoelens peilt. 'Als je het verleden blijft oprakelen, zal het beslist opnieuw gebeuren', klinkt het. Als Adi vraagt wat ze met hem zouden hebben gedaan als hij hen tijdens de dictatuur had benaderd, luidt het dreigende antwoord: 'Je hebt er geen idee van.' Van enig berouw of besef van morele verantwoordelijkheid is geen sprake. De protagonist Adi zou best een pseudoniem kunnen zijn en zijn volledige naam krijgen we nooit te horen - kan er alleen met stilzwijgen op reageren. Op de aftiteling aan het einde blijft de helft van de medewerkers anoniem uit angst voor represailles. Een treffend bewijs van het feit dat deze bladzijde uit de geschiedenis, een halve eeuw na datum, nog lang niet is omgeslagen.

Uit zijn vorige film bleek al dat 'documentaire' bij Oppenheimer niet staat voor een naïef realistische en lelijke film gedraaid met een schokkerige camera. The Look of Silence valt opnieuw op door de uiterst verzorgde beeldregie, fotografie en geluidsontwerp. Op 


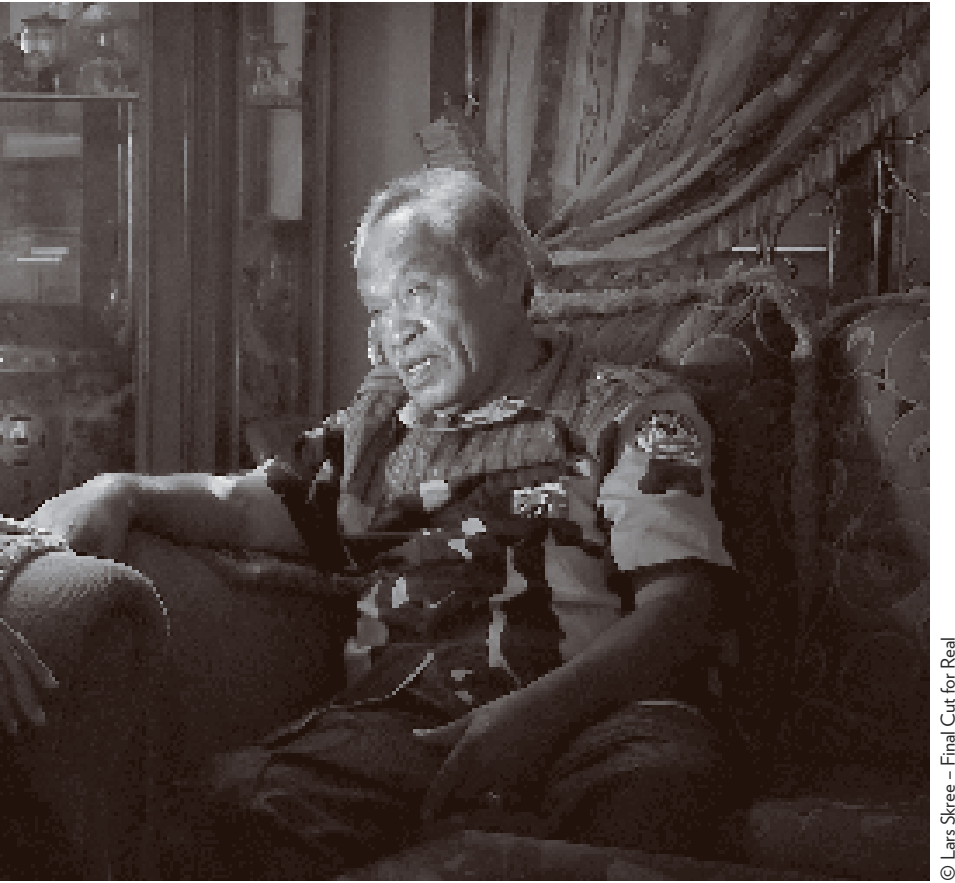

een paar live gezongen liederen na zit er geen muziek in de film. Het vertelritme is laag, haast hypnotiserend. Anders dan in het ongewild surrealistische The Act of Killing, waarin hij moordenaars hun gewelddaden liet ensceneren in de stijl van hun favoriete filmgenre, is de toon hier emotioneel, bijna schrijnend. Opmerkelijk is hoe Oppenheimer het visuele met het auditieve vervlecht, als een rode draad in de film. Voortdurend verbindt hij look (het brilmotief, het kijken naar filmbeelden) met silence (de ongemakkelijke stilten tijdens de interviews, het zwijgen van de diverse betrokkenen). De overlevenden doen er het zwijgen toe vanwege angst en trauma, de daders uit onvermogen om hun morele verantwoordelijkheid te erkennen.

Hiermee belanden we bij de kern van Oppenheimers audiovisuele strategie. Hij thematiseert het kijken via het steeds terugkerende brilmotief, ook treffend tot uiting gebracht in de filmaffiche, vanwaar een dader met een optometrische bril op de neus de toeschouwer aankijkt. De film begint met een scène waarin we de protagonist in een duistere kamer gebiologeerd naar een televisiescherm zien staren. Adi kijkt naar beelden van zijn eigen interviews die door Oppenheimer gedraaid werden. Op die manier
_ Adi met Amir Siahaan, een hooggeplaatste commandant van een doodseskader in de jaren zestig, en vandaag een paramilitaire leider.

wordt het kijken verdubbeld, want de situatie van Adi die naar het beeldscherm staart, is parallel met die van de toeschouwer die naar The Look of Silence kijkt. De verhouding tussen toeschouwer en film gaat deel uitmaken van de kijkervaring.

Vanaf het begin maakt Oppenheimer duidelijk dat we niet naar een historisch relaas zitten te kijken, maar naar beelden daarover. Zo sorteert hij een dubbel effect. Via een brechtiaanse ingreep maakt hij de kijker bewust van de artificiële situatie waarin die zich bevindt. Fundamenteler is dat hij op die manier de zogenaamde 'onmiddellijkheid' van het filmmedium op losse schroeven zet. Door de zintuiglijke directheid van film wordt wel eens vergeten dat de zevende kunst, zoals om het even welke kunstvorm, een aparte discipline is met een eigen taal, formele strategieën en technische kunstgrepen. Die denkfout wordt vooral gemaakt in het geval van de documentaire film, omdat die de werkelijkheid getrouw zou 'weerspiegelen', in tegenstelling tot de fictiefilm, die alleen maar de pretentie zou hebben om de kijker op aangename wijze te 'onderhouden' - een onkritische dichotomie die onmogelijk vol te houden is.

Oppenheimer plaatst vraagtekens bij het vermogen van film, of documentaire, om de werkelijkheid eenduidig af te beelden, laat staan die te beïnvloeden of te veranderen. Maar tegelijk maakt hij gebruik van het medium om een verborgen bladzijde uit de Indonesische geschiedenis aan het licht te brengen, want het voorgaande doet op geen enkele manier afbreuk aan de emotionele impact van de film. Niet alleen appelleert Oppenheimer aan het morele gevoel van de kijker, het lijkt wel of hij hem via zijn verhaal vol aandoenlijke en ijzingwekkende getuigenissen wil oproepen om mee te leven met de slachtoffers. Maar met zijn vertelstrategie maant hij hem aan om daarbij zijn verstand niet te verliezen, want beelden zijn bedrieglijk en moeten gepaard gaan met context, duiding en kritische reflectie.

Gorik de Henau

\section{Meer info}

In nummer 118 van Getuigen (september 2014) leest u een interview met Joshua Oppenheimer. 